\title{
Sketch Engine in Building a Lexical Minimum for Children
}

\author{
Gulshat R. Safiullina, Nuriya R. Davitova, Eva Lelakova
}

\begin{abstract}
Our article deals with such an aspect of computational linguistics as the construction of lexical minima cases using the Sketch Engine program as an example. The advent of computational linguistics has played an important role in the process of learning foreign languages. Thanks to computer technology, the process of learning foreign languages is greatly simplified and becomes more accessible. Among the many programs for learning foreign languages, we chose the Sketch Engine program, since it is a case manager and a tool for analyzing linguistic buildings, that is, collections of texts selected and processed according to certain rules, which are used as the basis for language research. This resource is software that combines a specialized search engine and a lot of buildings in different languages. We describe the program through the prism of corpus linguistics, consider the functions and capabilities of this program Sketch Engine in drawing up the lexical minimum for primary school age in English, Russian and German. In this paper, we conducted an experiment on drawing up a lexical minimum for schoolchildren, which consisted in selecting 300 most used words of the English language and saturating them with examples from the cases of the Sketch Engine program.
\end{abstract}

Keywords: lexical, minimum, dictionary, children, Sketch Engine, corpus.

\section{INTRODUCTION}

In the modern world, automated information technologies play a special role. When it comes to creating advanced information technologies, the problems of automatic processing of textual information presented in natural languages come to the fore. The problems of using natural language in systems of automatic information processing are handled by computer linguistics. This science originated relatively recently, but since then, significant scientific and practical results have been obtained in the field of computational linguistics. In our work we study the definition of computational linguistics. Considering the specificity of the phenomena studied, the main research methods are: descriptive method; scientific observation method; component analysis method. When conducting various linguistic studies, computer linguistics is increasingly being used.

According to Shemakina Yu.I. Computational linguistics is a scientific direction in the field of mathematical and computer modeling of intellectual processes in humans and animals when creating artificial intelligence systems, which aims to use mathematical models to describe natural languages [1:81]. An interesting point of view on the subject of computational linguistics in the Ukrainian researcher and

Revised Manuscript Received on November 08, 2019.

* Correspondence Author

Gulshat R. Safiullina, Kazan Federal University

Nuriya R. Davitova, Kazan Federal University

Eva Lelakova, University of Zilina Slovakia

cybernetics A.V. Anisimov. According to the scientist, computational linguistics deals with the search for algorithms and the computer implementation of human interaction with computers in the natural human language. " Thus, "in the case of successful implementation of computational linguistics projects, a person will be able to manage complex technical objects using voice commands or natural language texts [2: 57]. Linguistic means, which are created and applied in the field of computational linguistics, can be divided into two parts: declarative and procedural [3, p. 7]. The declarative part will include, first of all, dictionaries of units of language and speech, texts and various grammatical tables. By the procedural part - a means of manipulating units of language and speech, texts and grammatical tables. On this basis, the computer interface will refer to the procedural part of computational linguistics.

The Sketch Engine program was developed by representatives of the company Lexical computing and Masaryk University in Brno (Czech Republic) and is intended primarily for linguists engaged in the compilation of dictionaries [4]. The program is a product of lexical computing, the founder of which is the lexicographer and researcher Adam Kilgarif [5]. It is also important to note that this program is used when compiling dictionaries by the lexicographers of many well-known publishers, including Oxford University Press, Cambridge University Press, KDictionaries, Cornelsen, Shogakukan, Collins, Macmillan dictionary and Trojina [6]. Domestic and foreign linguists studied the possibility of using the program Sketch Engine. Yu.D.Apresyan, V.Yu.Apresyan, V.Baysa, P.Ryhlyy, T. Botma, R.Gous, V.Pinsloo and others [7-12]

The main purpose of the emergence of this program is to create a tool for studying the lexicographical properties of words. Learning languages can take place on the basis of buildings, as well as on the basis of statistical data. In addition, the researchers emphasize an empirical approach to the study of the behavior of words in a language. In other words, how a word can manifest itself in various texts, phrases or sentences. Some researchers also point out to the need of research in teaching collocations [13-17]

The program interface Sketch Engine offers more than 200 packages in 82 two languages. The largest corpus (TenTencorporafamily) can contain from 2 to 15 billion words.

As we have already noted, one of the features of the Sketch Engine program is a variety of languages, including Chinese, Czech, English (there are two versions of English: American and British), Estonian, Finnish, Japanese, etc. In addition, in the future, this program can be used to work with Turkic languages. 


\section{RESULTS AND DISCUSSION}

Consider the above provisions with specific examples. We have selected 300 words of the lexical minimum in English for younger students. The next stage was their translation into Russian and German.

Arranging these words in three columns in alphabetical order, we began to work on saturating the lexical minimum with examples. To guarantee the storage of the learned lexicon in a language learning environment, it is necessary to provide students with a context and demonstrate how the words are related [14-19-20]. Sketchengine allows to study words of various lexico-semantic groups in functional aspect [15, 16-18]. We emphasize that at the present stage of drawing up lexical minima, it is important to include in the body of the minimum relevant examples used by native speakers of speech in writing. We turn to the Sketch Engine program described by us and replenish our lexical minimum with examples.

\begin{tabular}{|c|c|c|c|c|c|}
\hline Apple & $\begin{array}{l}\text { The fruit of an apple } \\
\text { tree is apple. }\end{array}$ & Яблоко & $\begin{array}{l}\text { Фрукты, растущие на } \\
\text { яблонях- яблоки. }\end{array}$ & Der Apfel & $\begin{array}{l}\text { Der Apfel ist die Frucht, die } \\
\text { an einem Apfelbaum } \\
\text { wächst. }\end{array}$ \\
\hline Arm & He broke his arm. & Рука & Он сломал свою руку. & Der Arm & $\begin{array}{l}\text { Er hat sich den Arm } \\
\text { gebrochen. }\end{array}$ \\
\hline Air & $\begin{array}{l}\text { I was breathing fresh } \\
\text { air. }\end{array}$ & Воздух & Я дышал свежим воздухом. & Die Luft & $\begin{array}{l}\text { Ich habe die frische Luft } \\
\text { eingeatmet. }\end{array}$ \\
\hline Animal & $\begin{array}{l}\text { I love all kinds of } \\
\text { animals. }\end{array}$ & $\begin{array}{l}\text { Животн } \\
\text { ое }\end{array}$ & $\begin{array}{l}\text { Я люблю все виды } \\
\text { животных. }\end{array}$ & Das Tier & $\begin{array}{l}\text { Ich liebe alle Arten von } \\
\text { Tieren. }\end{array}$ \\
\hline Art & $\begin{array}{l}\text { Hapkido is a Korean } \\
\text { martial art. }\end{array}$ & $\begin{array}{l}\text { Искусст } \\
\text { во }\end{array}$ & $\begin{array}{l}\text { Хапкидо - Корейское } \\
\text { боевое Искусство. }\end{array}$ & Die Kunst & $\begin{array}{l}\text { Hapkido ist eine } \\
\text { koreanische Kampfkunst. }\end{array}$ \\
\hline Age & $\begin{array}{l}\text { I am the same age as } \\
\text { you. }\end{array}$ & Возраст & $\begin{array}{l}\text { Я такого же возраста, что и } \\
\text { ты. }\end{array}$ & Das Alter & $\begin{array}{l}\text { Ich bin im gleichen Alter } \\
\text { wie du. }\end{array}$ \\
\hline All & All was well. & Bcë & Всё было хорошо. & Alles & Alles war gut. \\
\hline Always & I will always love you. & Всегда & Я буду всегда любить тебя. & Immer & $\begin{array}{l}\text { Ich werde dich immer } \\
\text { lieben. }\end{array}$ \\
\hline Alone & She lives alone. & $\begin{array}{l}\text { Один/Од } \\
\text { инокий }\end{array}$ & Она живет одна. & Allein & Sie lebt allein. \\
\hline $\mathrm{Be}$ & $\begin{array}{l}\text { He wants to be a good } \\
\text { man. }\end{array}$ & Быть & $\begin{array}{l}\text { Он хочет быть хорошим } \\
\text { человеком. }\end{array}$ & Sein & $\begin{array}{l}\text { Er will ein guter Mensch } \\
\text { sein. }\end{array}$ \\
\hline Brother & Her brother is an actor. & Брат & Её брат - актер. & Der Bruder & $\begin{array}{l}\text { Ihr Bruder ist der } \\
\text { Schauspieler. }\end{array}$ \\
\hline Body & $\begin{array}{l}\text { The human body is a } \\
\text { complex system. }\end{array}$ & Тело & $\begin{array}{l}\text { Человеческое тело- это } \\
\text { сложная система. }\end{array}$ & Der Körper & $\begin{array}{l}\text { Der menschliche Körper ist } \\
\text { ein komplexes System. }\end{array}$ \\
\hline Building & The building is of brick. & Здание & Здание из кирпича. & $\begin{array}{l}\text { Das } \\
\text { Gebäude }\end{array}$ & $\begin{array}{l}\text { Das Gebäude ist aus } \\
\text { Ziegeln. }\end{array}$ \\
\hline Bee & $\begin{array}{l}\text { Bees live in the } \\
\text { colonies. }\end{array}$ & Пчела & Пчелы живут колониями. & Die Biene & $\begin{array}{l}\text { Bienen leben in einer } \\
\text { Kolonie. }\end{array}$ \\
\hline Blue & I have blue eyes. & Синий & Мои глаза синего цвета. & Blau & Ich habe blaue Augen. \\
\hline Black & I have a black car. & Черный & У меня есть черная машина & Schwarz & $\begin{array}{l}\text { Ich habe ein schwarzes } \\
\text { Auto. }\end{array}$ \\
\hline Brown & He wore a brown coat. & $\begin{array}{l}\text { Коричне } \\
\text { вый }\end{array}$ & $\begin{array}{l}\text { Он носил коричневое } \\
\text { пальто. }\end{array}$ & Braun & $\begin{array}{l}\text { Er trug einen braunen } \\
\text { Mantel. }\end{array}$ \\
\hline $\mathrm{Bad}$ & $\begin{array}{l}\text { Yesterday was a bad } \\
\text { day. }\end{array}$ & Плохой & Вчера был плохой день. & Schlecht & $\begin{array}{l}\text { Gestern war ein schlechter } \\
\text { Tag. }\end{array}$ \\
\hline Baby & $\begin{array}{l}\text { The baby is six months } \\
\text { old now. }\end{array}$ & Малыш & Малышу сейчас 6 месяцев. & Das Baby & $\begin{array}{l}\text { Das Baby ist jetzt sechs } \\
\text { Monate alt. }\end{array}$ \\
\hline Big & This is a big mistake. & $\begin{array}{l}\text { Большо } \\
\text { й }\end{array}$ & Это - большая ошибка. & Gro $\beta$ & Das ist ein großer Fehler. \\
\hline Before & $\begin{array}{l}\text { You knew her before } \\
\text { she came here. }\end{array}$ & До & $\begin{array}{l}\text { Вы знали до того, как она } \\
\text { пришла сюда. }\end{array}$ & Bevor & $\begin{array}{l}\text { Du kanntest sie, bevor sie } \\
\text { hergekommen ist. }\end{array}$ \\
\hline Because & $\begin{array}{l}\text { I was there because I } \\
\text { was afraid. }\end{array}$ & $\begin{array}{l}\text { Потому } \\
\text { что }\end{array}$ & $\begin{array}{l}\text { Я был там, потому что } \\
\text { боялся. }\end{array}$ & Weil & $\begin{array}{l}\text { Ich war dort, weil ich Angst } \\
\text { hatte. }\end{array}$ \\
\hline Book & Give me this book. & Книга & Дай мне эту книгу. & Das Buch & Gib mir dieses Buch. \\
\hline Boy & The boy plays football. & Мальчик & Мальчик играет в футбол. & Der Junge & Der Junge spielt Fußball. \\
\hline But & $\begin{array}{l}\text { Yes, but my little } \\
\text { brother's here. }\end{array}$ & Ho & $\begin{array}{l}\text { Да, но мой младший брат } \\
\text { здесь }\end{array}$ & Aber & $\begin{array}{l}\text { Ya, aber mein kleiner } \\
\text { Bruder ist hier. }\end{array}$ \\
\hline
\end{tabular}




\begin{tabular}{|l|l|l|l|l|l|}
\hline Cat & The cat sleeps all day. & Кот & Кот спит целый день. & Der Kater & $\begin{array}{l}\text { Der Kater schläft den } \\
\text { ganzen Tag. }\end{array}$ \\
\hline Clock & $\begin{array}{l}\text { The clock has just } \\
\text { struck three. }\end{array}$ & Часы & $\begin{array}{l}\text { Часы только что пробили } \\
\text { три. }\end{array}$ & Die Uhr & $\begin{array}{l}\text { Die Uhr hat gerade drei } \\
\text { geschlagen. }\end{array}$ \\
\hline Chicken & The chicken clucks. & Курица & Курица кудахчет. & Die Henne & Die Henne gluckt. \\
\hline Child & He is still a child. & Ребенок & Он все еще ребенок. & Das Kind & Er ist noch ein Kind. \\
\hline Color & $\begin{array}{l}\text { Green is my favorite } \\
\text { color. }\end{array}$ & Цвет & $\begin{array}{l}\text { Зеленый - мой любимый } \\
\text { цвет. }\end{array}$ & Die Farbe & $\begin{array}{l}\text { Grün ist meine bevorzugte } \\
\text { Farbe. }\end{array}$ \\
\hline Come & $\begin{array}{l}\text { Come see me tonight } \\
\text { after the theater. }\end{array}$ & $\begin{array}{l}\text { Приходи } \\
\text { ть }\end{array}$ & $\begin{array}{l}\text { Приходите ко мне сегодня } \\
\text { вечером после театра. }\end{array}$ & Kommen & $\begin{array}{l}\text { Kommen Sie heute nach } \\
\text { dem Theater bei mir vorbei. }\end{array}$ \\
\hline
\end{tabular}

The purpose of this lexical minimum was to match the examples, so we selected examples with a completely identical value.

The word building is accompanied by an example of The building is of brick. Russian translation of the word building building. This word in our lexical minimum is presented along with an illustrative example of a brick building. The German version of the lexeme is Das Gebäude, which is reflected in the sentence of Das Gebäude ist aus Ziegeln.

The next example is the word date in the sentence The date is yet unknown. The Russian equivalent of this word is the word date, illustrated by the sentence. The date is still unknown. The sentence Das Datum ist noch unbekannt contains the German version of this word - Das Datum.

In this lexical minimum, we collected the most used verbs of the English language. For example, using the open word as an example, we chose the He opened window. In Russian, this word is translated as open and presented in the sentence. He opened the window. The German equivalent of this word öffnen is expressed by the sentence Er öffnete das Fenster.

We also considered the most used prepositions. For example, in the sentence I have a present for you we can find the preposition for, which is expressed by the word for in the sentence in Russian. I have a gift for you. In German, the word is translated as für, which is presented in the sentence Ich habe ein Geschenk für dich.

Much attention was paid and numeral. This lexical minimum presents examples of numbers from one to twelve. As an example, we take the number seven in the sentence There Are seven wonders of the world. The German translation of the word seven - sieben, presented in the sentence Es gibt sieben Wunder der Erde. Offer There are seven wonders of the world illustrated by its Russian version.

\section{SUMMARY}

The program for learning languages Sketch Engine has unique features and functions. After examining each function in detail and illustrating it with examples, we can divide all functions into two large groups: the functions necessary to extract lexicographical data, and the functions with which we can create our own corpus.

The functions necessary for extracting lexicographical data are, in our opinion, most useful for students, because with their help we can find specific words in various contexts, find phrases and phrases with a given word, and, therefore, replenish our vocabulary and improve written and oral skills. In this paper, we conducted an experiment on drawing up a lexical minimum for schoolchildren, which consisted in selecting 300 most used words of the English language and saturating them with examples from the cases of the Sketch
Engine program. Thus, we have shown how this program can be used by lexicographers in compiling dictionaries.

\section{CONCLUSIONS}

The Sketch Engine program was created quite recently, which means there may be additional developments and capabilities. One of these innovations will be the creation of buildings in the Turkic languages and in the future the developers plan to create a platform for learning Russian and Tatar languages, which means that further research will be needed on the capabilities and functions of this program.

\section{ACKNOWLEDGEMENTS}

The work is performed according to the Russian Government Program of Competitive Growth of Kazan Federal University.

\section{REFERENCES}

1. Shemakin Yu. I. the Beginning of computer linguistics Moscow: Publishing house of Moscow state University, A/O "Rosvuznauka", 1992. - $181 \mathrm{p}$.

2. Anisimov A. Computational linguistics for all: Myths. Algorithms. Language. - Kiev: Naukovadumka, 1991. - 208 p

3. Belonogov G. G., Kalinin Yu. P., Khoroshilov A. A. Computer linguistics and perspective information technologies. Moscow: Russian world, 2004. - 240 p.

4. Site Sketch Engine [Electronic resource]. - Mode of access: https://www.sketchengine.co.uk free (date accessed: 10.01.2018)

5. Kilgarriff A., Rychly P., Baisa V. Extrinsic Corpus Evaluation with a Collocation Dictionary Task [Electronic resource]. - Режим доступа: http://www.lrec-conf.org/proceedings/lrec2014/pdf/52_Paper.pdf, свободный (date accessed: 25.05.2019)

6. Kirpichnikova A. scientists of KFU will cooperate with developers of the Sketch Engine program [Electronic resource]. - Mode of access: https://kpfu.ru/philology-culture/struktura-instituta/otdelenie..., free (date accessed: 20.02.2018)

7. Apresyan Y. D. Selected works, vol. The integrated description of language and systemic lexicography. - Moscow: School "Languages of Russian culture", 2005. - 379 p.

8. Apresjan V., Baiza V. RuSkELL: Online Language Learning Tool for Russian Language [Electronic resource]. - Mode of access: http://euralex.org/wp-content/themes/euralex/proceedings/Euralex $\% 2$ 02016/euralex_2016_030_p292.pdf free (date accessed: 05.05.2019)

9. Apresjan V. Dictionary as an Instrument of Linguistic Research [Electronic resource]. - URL: http://euralex.org/wp-content/ themes/euralex/ proceedings/Euralex\%202016/ euralex_2016_020_p224.pdf, (date accessed: 14.05.2018)

10. Baiza V. Multilingual CPA: Linking Verb Patterns across Languages [Electronic resource]. - URL: http://euralex.org/wp-content/ themes/euralex/proceedings/Euralex\%202016/euralex_2016_044_p4 10.pdf, (date accessed: 18.05.2019)

11. Kilgarriff A., Rychly P., Baisa V. Extrinsic Corpus Evaluation with a Collocation Dictionary Task [Electronic resource]. - URL: http://www.lrec-conf.org/proceedings/lrec2014/pdf/52_Paper.pdf, (date accessed: 21.05.2019) 
12. Theo J.D. Bothma, Rufus H. Gouws, Danie J. Prinsloo The Role of E-lexicography in the Confirmation of Lexicography as an Independent and Multidisciplinary Field [Electronic resource]. - URL: http://euralex.org/wp-content/themes/euralex/proceedings/ Euralex\%202016/ euralex_2016_008_p109.pdf, (date accessed: 26.05.2019)

13. Varlamova, E.V., Naciscione, A., Tulusina, E.A. (2016) A study on the phenomenon of collocations: Methodology of teaching English and German collocations to Russian students // International Journal of Environmental and Science Education. 11(6), ijese.2016.116, pp. 1275-1284.

14. Noskova A.I. Development of lexical competence in learning Spanish as a foreign language // EDULEARN17, the 9th annual International Conference on Education and New Learning Technologies, July 3rd-5th, 2017. - Barcelona, Spain, 2017. - Pp: 331-335.

15. Tarasova F.K, Tarasov A.M., The phraseosemantic group of «family relations « in the system of proverbs and sayings with «food component in languages with different structures//Analele Universitatii din Craiova - Seria Stiinte Filologice, Lingvistica. - 2018. - Vol.40, Is.1-2. - P.191-201.

16. Garipova Elza V, Sadykova Aida G., Tarasova Fanuza Kh, Functional Aspect Of Linguistic Identity In Russian Blogosphere//MODERN JOURNAL OF LANGUAGE TEACHING METHODS. - 2018. Vol.8, Is.10. - P.378-383

17. Sazesh, A., \& Siadat, S. A. The Relationship between Quantum Management and Organizational Agility in Ministry of Roads and Urban Development of Golestan Province, Iran. Dutch Journal of $\begin{array}{llll}\text { Finance and } & \text { Management, (2018). 2(2), } 51 .\end{array}$ https://doi.org/10.29333/djfm/5827

18. Piteira, M., Costa, C. J., \& Aparicio, M. Computer Programming Learning: How to Apply Gamification on Online Courses?. Journal of Information Systems Engineering \& Management, (2018). 3(2), 11.

19. Sulistyaningsih, D., Purnomo, \& Aziz, A. Development of Learning Design for Mathematics Manipulatives Learning based on E-learning and Character Building. International Electronic Journal of Mathematics $\quad$ Education, (2019).14(1), 197-205. https://doi.org/10.29333/iejme/3996

20. Kozhabergenova, G. E., Taubaeva, S., Bulatbayeva, A. A., Kabakova, M. P., \& Asanov, N. A. The Stewardship of School Counselor Education in Higher Educational Establishments. Opción, (2018). 34(85-2), 386-414. 